\title{
Hubungan Cryotherapy terhadap Mukositis Oral pada Pasien Kanker Payudara dengan Kemoterapi di Ruangan Kemoterapi Rumah Sakit M. Djamil Padang
}

\author{
Anggra Trisna Ajani ${ }^{1}$, Hema Malini ${ }^{2}$, Rika Fatmadona ${ }^{2}$
}

\begin{abstract}
Abstrak
Mukositis oral merupakan salah satu efek samping yang paling sering muncul pada pasien kanker yang menjalani kemoterapi. Mukositis oral dapat mengakibatkan terjadi gangguan fungsi integritas rongga mulut sehingga menimbulkan rasa nyeri hebat yang dapat mengakibatkan penundaan pengobatan kemoterapi untuk siklus berikutnya. Mukositis oral juga dapat mengurangi dosis pada kemoterapi yang akan dijalani oleh pasien sehingga pengobatan kanker tidak bisa optimal di lakukan. Tujuan: Menentukan hubungan cryotherapy terhadap mukositis oral pada pasien kanker payudara dengan kemoterapi. Metode: Penelitian ini merupakan survei analitik dengan pendekatan cross sectional. Teknik pengambilan sampel pada penelitian ini adalah consecutive sampling. Ada 32 orang responden yang menjadi sampel, terdiri dari dua kelompok. Intervensi pada penelitian ini yaitu cryotherapy. Cryotherapy diberikan sewaktu kemoterapi dilaksanakan sampai dengan 14 hari setelah kemoterapi dengan durasi 20 menit sekali sehari. Penilaian mukositis oral dengan menggunakan lembaran observasi OAG (Oral Assesment Guide). Penilaian OAG di lakukan sebelum cryotherapy dan hari ke-14 setelah kemoterapi. Hasil: Ada hubungan cryotherapy dengan penurunan skala mukositis oral pada pasien kanker payudara ( $p$ value 0,013 ). Cryotherapy dapat menyebabkan terjadinya vasokonstriksi pada daerah rongga mulut, mengurangi aliran darah yang membawa obat kemoterapi mencapai area mukosa mulut lebih sedikit. Simpulan: Cryotherapy mampu menurunkan skala mukositis oral pada pasien kanker payudara dengan kemoterapi kombinasi 5-fluorouracil.
\end{abstract}

Kata kunci: kemoterapi, mukositis oral, cryotherapy

\begin{abstract}
Oral mucositis is one of the most frequent side effects that arise in cancer patients undergoing chemotherapy. Oral mucositis can lead to malfunction integrity of the oral cavity, causing severe pain, which can result in delays for the next cycle of chemotherapy treatment. Oral mucositis can also reduce the dose of chemotherapy to be live by the patient so that optimal cancer treatment can not be done. Objectives: To determined the relationship between cryotherapy and oral mucositis in breast cancer patients with chemotherapy. Methods: This research was an analytic survey with a cross-sectional approach. The sampling technique in this research was consecutive sampling. 32 respondents consisted of two groups. Intervention is cryotherapy. Cryotherapy was given during chemotherapy carried out until 14 days after the chemotherapy with a duration of 20 minutes once a day. Oral mucositis assessment used observation sheet OAG (Oral Assessment Guide). OAG assessment was done before cryotherapy and the $14^{\text {th }}$ day after chemotherapy. Results: The relationship between cryotherapy and a reduction scale of oral mucositis in patients with breast cancer ( $p$-value 0.013). Cryotherapy can cause vasoconstriction in the area of the oral cavity, reducing blood flow that carries the chemotherapy drugs reach the area of the oral mucosa less. Conclusion: Cryotherapy can reduce the scale of oral mucositis in breast cancer patients with a combination of 5-fluorouracil chemotherapy.
\end{abstract}

Keywords: chemotherapy, oral mucositis, cryotherapy 


\section{PENDAHULUAN}

Kanker payudara adalah tumor ganas pada payudara yang berasal dari kelenjar disekitar area payudara. ${ }^{1}$ Kanker payudara merupakan penyebab kematian kedua setelah kanker servik pada wanita. ${ }^{2}$ Angka kejadian kanker payudara di Indonesia setiap tahunnya mengalami peningkatan sebanyak 1,4 per 1000 penduduk pada tahun 2013 menjadi 1,7 per 1000 penduduk pada tahun 2018. Sumatera Barat merupakan provinsi ke-2 terbanyak kasus kanker payudara setelah Yogyakarta dengan jumlah 2,477 per 1000 penduduk. $^{2}$ Indonesia di ramalkan pada tahun 2030 akan mengalami peningkatan jumlah pasien kanker sampai 7 kali lipat. $^{3}$

Penatalaksanaan kanker payudara salah satunya adalah kemoterapi. ${ }^{4}$ Kemoterapi pada kanker payudara Kemoterapi 5-fluorouracil biasanya diberikan melalui intravena baik tunggal atau kombinasi. ${ }^{5}$ Agen kemoterapi 5-fluorouracil untuk kanker payudara diberikan kombinasi bersama dengan obat lain yaitu cylophosphamide/methotrexate/5-fluorouracil (CMF), cyclophosphamide/doxorubicin/andriamicin/5fluorouracil (CAF), cyclosphosphamide/epirubicin/5-fluorouracil (CEF). Agen kombinasi ini mempunyai interval 3-4 minggu/21 hari selama 6 siklus. $^{3}$ 5-fluorouracil pada pasien yang menjalani kemoterapi memiliki waktu paruh 5-20 menit. ${ }^{6}$ 5-fluorouracil secara tidak langsung dapat merusak lapisan sel epitel basal sehingga mengakibatkan terjadinya kematian pada sel klonogenik dan atrofi pada mukosa serta ulserasi yang disebut dengan mukositis oral. ${ }^{7}$ Prevalensi terjadinya mukositis oral dengan menggunakan terapi 5-fluoruoracil sebanyak $80 \%$ pada pasien kanker darah. ${ }^{8}$

Mekanisme terjadinya mukositis oral dibagi atas 5 fase yaitu fase peradangan, fase transkrip, fase amplifikasi, fase ulserasi dan fase penyembuhan. ${ }^{9}$ Fase peradangan sampai ke fase ulserasi biasanya berlangsung selama 2 minggu pertama setelah kemoterapi dilaksanakan atau 7-14 hari setelah kemoterapi. Fase penyembuhan di mulai pada minggu ke-3. ${ }^{7}$ Mukositis oral dapat mengakibatkan terjadinya gangguan fungsi integritas rongga mulut, menimbulkan rasa nyeri hebat yang menyebabkan penundaan pengobatan kemoterapi siklus berikutnya. ${ }^{10}$ Mukositis oral juga dapat mengurangi dosis pada kemoterapi yang akan di jalani oleh pasien pada siklus berikutnya sehingga pengobatan kanker tidak bisa optimal di laksanakan. ${ }^{11}$

Berbagai macam penatalaksanaan terapi modalitas keperawatan untuk mengatasi mukositis oral salah satunya yaitu cryotherapy. ${ }^{12}$ Cryotherapy adalah terapi dingin dengan menggunakan es batu (chip) untuk mencegah atau menurunkan mukositis oral pada pasien kanker khususnya kanker payudara yang menjalani kemoterapi. ${ }^{13}$ Cryotherapy direkomendasikan dilaksanakan selama 30 menit, berguna untuk mencegah terjadinya mukositis oral akibat kemoterapi 5fluorouracil melalui bolus. ${ }^{14}$ Cryotherapy berfungsi sebagai vasokonstriksi pada daerah sekitar rongga mulut, menyebabkan aliran darah berkurang dan lambat sehingga efek samping sitotoksik kemoterapi yang muncul lebih kecil ${ }^{15}$ Cryotherapy merupakan terapi modalitas keperawatan yang paling mudah diakses, lebih murah, praktis, efisien, hemat biaya, serta dapat mencegah dan menurunkan skala mukositis oral. ${ }^{11}$

Peneliti melakukan studi pendahuluan di RSUP Dr M Djamil Padang dengan melakukan wawancara pada perawat ruangan. Hasil yang didapat bahwa perawat menganjurkan kepada pasien yang menjalani kemoterapi untuk banyak mengkonsumsi buah, sayur dan minum air hangat. Perawat juga menganjurkan agar pasien dapat menggosok gigi dengan menggunakan sikat gigi yang lembut. Perawat ruangan mengatakan tidak ada SOP khusus untuk perawatan oral hygiene pada pasien yang menjalani kemoterapi.

Merujuk pada penelitian sebelumnya dan fenomena di lapangan, maka peneliti tertarik untuk melakukan penelitian. Penelitian ini dilakukan untuk mengetahui adanya hubungan cryotherapy terhadap penurunan skala mukositis oral pasien kanker payudara di RSUP Dr M Djamil Padang tahun 2019.

\section{METODE}

Penelitian ini menggunakan desain survey analitik dengan pendekatan cross sectional. Teknik pengambilan sampel secara consecutive sampling. Consecutive sampling adalah pemilihan sampel dengan memilih semua individu yang ditemui di ruangan kemoterapi sesuai dengan kriteria inklusi dan eklusi sampai dengan jumlah responden terpenuhi. Kriteria 
inklusi pada penelitian ini adalah berusia $\geq 17$ tahun, pasien bersedia menjadi responden, pasien kanker payudara dengan kemoterapi kombinasi 5-fluorouracil yang mengikuti lebih dari 1 siklus kemoterapi. Kriteria eklusi yaitu pasien yang sensitif terhadap es, obat kemoterapi kombinasi dengan Oxiplatin, pasien yang mempunyai penyakit komplikasi (DM, immunosupresi, dan vasculer).

Cryotherapy dilakukan pada saat kemoterapi dimulai sampai 14 hari setelah kemoterapi. Cryotherapy dilaksanakan sekali setiap hari dengan waktu durasi kurang lebih 20 menit. Cryotherapy diberikan setelah responden gosok gigi. Menggososk gigi dilakukan dengan menggunakan sikat gigi yang lembut dan odol sensitif yang telah disediakan oleh peneliti.

Alat ukur yang digunakan pada penelitian ini adalah lembaran observasi OAG (Oral Assessment Guide). Penilaian OAG dievaluasi setelah dilakukan perlakuan pada hari ke-14 setelah kemoterapi (post test). Tujuan lembaran observasi OAG adalah untuk memperoleh informasi mengenai responden tentang data demografi seperti nama, umur, pekerjaan, jenis kelamin, lama kemoterapi, BB/TB, jenis kanker, stadium dan siklus kemoterapi. Peneliti menggunakan uji validitas instrumen mukosotis oral dengan menggunakan uji korelasi pearson product moment dengan $r$ hasil $0,647-0,759$. valid $(r$ hasil $>t$ tabel $; r$ tabel < 0,647). Uji reliabilitas dengan cronbach coefficient alpha di peroleh hasil sebesar 0,959 yang artinya bahwa secara statistik alat ukur pada stadium mukositis oral dianggap reliabel. Analisa data menggunakan analisa univariat yang disajikan dalam bentuk tabel distribusi frekuensi dan analisa bivariat dengan menggunakan uji chi squar, dimana $p<0,05$.

HASIL

Penelitian ini terdiri dari dua kelompok perlakuan. Kelompok intervensi (cryotherapy) berjumlah 16 orang responden. Penelitian dilakukan selama 14 hari, cryotherapy diberikan sekali sehari selama 20 menit. Karakteristik dari 32 sampel dapat dilihat pada Tabel 1. Tidak ada perbedaan karakteristik yang ditemukan pada kedua kelompok. Hal ini dapat di lihat sebagai berikut:
Tabel 1. Distribusi frekuensi karakteristik responden umur, pendidikan dan pekerjaan pasien kanker payudara tahun 2019

\begin{tabular}{lcccc}
\hline Variabel & \multicolumn{2}{c}{ Intervensi } & \multicolumn{2}{c}{ Kontrol } \\
& $\mathbf{n}$ & $\%$ & $\mathbf{n}$ & $\%$ \\
\hline Umur & & & & \\
Dewasa awal & 1 & 6,25 & 2 & 12,5 \\
Dewasa akhir & 6 & 37,5 & 5 & 31,25 \\
Lansia awal & 8 & 50,0 & 7 & 43,75 \\
Lansia akhir & 1 & 6,25 & 2 & 12,5 \\
\hline Pendidikan & & & & \\
Rendah & 8 & 50,0 & 6 & 37,5 \\
Tinggi & 8 & 50,0 & 10 & 62,5 \\
\hline Pekerjaan & & & & \\
Tidak bekerja & 10 & 62,5 & 11 & 68,75 \\
Bekerja & 6 & 37,5 & 5 & 31,25 \\
\hline
\end{tabular}

Tabel 1 menunjukkan bahwa usia responden pada kelompok intervensi lebih banyak pada usia lansia awal (46-55 tahun) yang berjumlah 8 orang (50\%), pada responden yang mempunyai pendidikan tinggi (SMAPT) berjumlah 8 orang (50\%). Responden yang tidak bekerja yaitu sebanyak 10 orang $(62,5 \%)$. Pada kelompok kontrol paling banyak pada usia lansia awal (46-55 tahun) sebanyak 6 orang (37,5\%). Responden yang bependidikan tinggi berjumlah 10 orang $(62,5 \%)$. Pekerjaan responden yang terbanyak tidak bekerja berjumlah 11 orang $(68,75 \%)$.

Tabel 2. Hubungan mukositis oral pre-test mukositis oral post test pasien kanker payudara dengan kemoterapi pada kelompok kontrol tahun 2019

\begin{tabular}{cccc}
\hline \multirow{2}{*}{ Pre test } & \multicolumn{2}{c}{ Post test } & Total \\
\cline { 2 - 3 } & Ringan & Normal & \\
\hline Sedang & $5(100 \%)$ & $0(0 \%)$ & $6(100 \%)$ \\
Ringan & $3(27,3 \%)$ & $8(72,7 \%)$ & $10(100 \%)$ \\
Total & $8(50 \%)$ & $8(50 \%)$ & $16(100 \%)$ \\
\hline
\end{tabular}

Tabel 2. menunjukkan bahwa setelah dilakukan cryotherapy dari 16 responden, kategori mukositis skala sedang pada mukositis oral post test setelah diberikan cryotherapy menjadi mukositis oral skala ringan sebanyak 5 orang (100\%), mukositis oral dengan skala 
menetap yaitu ringan berjumlah 3 orang $(27,3 \%)$ dan mukositis oral yang mengalami penyembuhan (normal) berjumlah 8 orang $(72,7 \%)$ dengan $p<0,05$. Jadi dapat disimpulkan cryotherapy mempunyai hubungan dengan penurunan skala mukositis oral pada pasien kanker payudara.

Hubungan cryotherapy terhadap mukositis oral pada pasien kanker payudara dengan obat kemoterapi kombinasi 5-fluorouracil pada kelompok kontrol, tanpa diberikan perlakuan dengan jumlah responden sebanyak 16 orang dapat dilihat pada tabel dibawah ini.

Tabel 3. Hubungan mukositis oral pre-test mukositis oral post test pasien kanker payudara dengan kemoterapi pada kelompok kontrol tahun 2019

\begin{tabular}{ccccc}
\hline Pre test & Sedang & $\begin{array}{r}\text { Post test } \\
\text { Ringan }\end{array}$ & Normal & p \\
\hline Sedang & 3 & 2 & 1 & 0,032 \\
& $(50 \%)$ & $(33,3 \%)$ & $(16,7 \%)$ & \\
Ringan & 0 & 9 & 1 & \\
& $(0 \%)$ & $(90 \%)$ & $(10 \%)$ & \\
Total & 3 & 11 & 2 & \\
& $(18,75 \%)$ & $(68,75)$ & $(12,5 \%)$ & \\
\hline
\end{tabular}

Hasil Tabel 3 menunjukkan pada kelompok kontrol didapat bahwa mukositis oral pre test skala sedang setelah kemoterapi pada hari ke-14 memperoleh hasil yaitu mengalami mukositis oral skala sedang berjumlah 3 orang (50\%), mukositis oral skala ringan berjumlah 2 orang $(33,3 \%)$, tidak mengalami mukositis oral atau sembuh berjumlah 1 orang (16,7\%). Sedangkan pada pre test dapat $\mathrm{p}=0,032$, artinya terdapat hubungan yang signifikan antara kelompok kontrol dengan penurunan skala mukositis oral. Mukositis oral ringan setelah 14 setelah kemoterapi mengalami perubahan mukositis menjadi mukositis oral skala sedang tidak ada, mukositis skala ringan berjumlah 9 orang (90\%), tidak mengalami mukositis oral atau sembuh berjumlah 2 orang $(12,5 \%)$ dengan $p$ value 0,032 , artinya adanya hubungan kelompok kontrol terhadap penurunan mukositis oral.

\section{PEMBAHASAN}

Hasil penelitian ini menunjukkan bahwa cryotherapy dapat menurunkan skala mukositis oral setelah dilakukan intervensi selama 14 hari setiap hari selama 20 menit. 5-fluorouracil mempunyai waktu paruh yang sangat pendek yaitu 5- 20 menit. ${ }^{16}$ Cryotherapy dapat bekerja pada daerah sekitar rongga mulut dimana rongga mulut mengalami vasokonstriksi akibat mengulum es batu (chip), hal ini menyebabkan obat kemoterapi khususnya 5-fluorouracil kombinasi dengan obat yang lain dapat mengurangi atau memperlambat aliran darah sehingga efek sitotoksik pada daerah rongga mulut dapat diminimalisir ${ }^{7}$

Kemoterapi 5- fluorouracil dapat merusak lapisan pada sel epitel basal secara langsung, menyebabkan aktifnya Reaktif Oksigen Spesies (ROS). Kerusakan sel menyebabkan timbulnya peningkatan reaksi radang. ${ }^{16}$ hal ini dapat mengaktifkan Nuclear Faktor Kappa $B$ (NFkB). TNF- $\lambda$ yang aktif secara langsung akan mengaktifkan NFkB, Mitogen-Activated Protein Kinase (MAPK) dan sphyngomyelinase patways. ${ }^{17} \mathrm{Hal}$ ini dapat memperluas kerusakan sel basal epitel dan jaringan sehingga menimbulkan eritema dan pengecilan epitel. Proses ini biasanya terjadi pada hari ke 4-5 setelah kemoterapi dilakukan. ${ }^{15}$ Eritema akan menjadi ulserasi pada rongga mulut pada saat menelan dan mengunyah yang menimbulkan trauma. Fase ulserasi pada tahap terbentuknya mukositis oral akan berlangsung selama minggu ke-2 atau 7-14 hari setelah kemoterapi. ${ }^{4}$

Mukositis oral akan bertambah berat dan parah sewaktu agen obat kemoterapi yang diberikan dalam dosis yang tinggi, usia yang semakin lanjut, jenis kelamin perempuan, jenis obat kemoterapi, jadwal kemoterapi yang berulang (siklus kemoterapi), status nutrisi yang buruk, di tambah lagi dengan kondisi kebersihan mulut yang buruk. ${ }^{11}$ Menurut penelitian Hasibuan di Texas pada pasien yang menjalani kemoterapi dengan tumor padat (tumor usus, tumor recti, tumor paru dan lainnya) didapatkan bahwa mukosotis oral dapat menyebabkan berkurangnya 2 kali dosis pengobatan kemoterapi. Mukositis oral dapat meningkatkan terjadinya resiko infeksi yang lebih tinggi. Selama pasien menjalani siklus kemoterapi sebanyak $(73 \%)){ }^{18}$

Pada penelitian ini dapat dilihat kelompok intervensi setelah dilakukan ryotherapy berjumlah 8 orang $(50 \%)$ dengan mukositis oral skala ringan. Pada kelompok kontrol tidak diberikan perlakuan apapun terhadap mukositis oral didapat 3 orang $(18,75 \%)$ yang mengalami mukositis oral skala sedang, 11 orang $(68,75 \%)$ dengan mukositis oral skala ringan, dan 2 
orang $(12,5 \%)$ dengan skala normal atau sembuh. Dapat disimpulkan dari dua kelompok penelitian ini, cryotherapy lebih banyak yang mengalami penurunan skala mukositis oral (sembuh). Dua kelompok penelitian ini lebih dominan berada pada usia lansia awal (46-55 tahun). Hal ini dapat mempengaruhi proses penurunan skala mukositis oral.

Cryotherapy selain menimbulkan vasokontriksi pada rongga mulut, sensasi dingin dari es chip juga dapat menurunkan eksitabilitas akhiran saraf bebas sehingga menurunkan kepekaan terhadap rangsang nyeri. ${ }^{19,20}$ Hasil studi Hasibuan didapat bahwa adanya hubungan secara signifikan dengan berkurangnya derajat nyeri terhadap keparahan mukositis oral. ${ }^{18}$ Durasi pemberian cryotherapy dilakukan 5 menit sebelum kemoterapi, selama kemoterapi dan 5 menit sesudah kemoterapi dengan total waktu 30 menit pemberian sekali sehari. Hasil penelitian ini mendapatkan bahwa, kelompok Cryotherapy lebih rendah angka kejadian mukositis oral (45\%) dari pada kelompok kontrol. ${ }^{21}$ Sedangkan penelitian yang dilakukan oleh Heydari et al, didapat bahwa untuk insiden mukositis oral dalam kelompok cryotherapy dengan menggunakan skala patient-judge oral mukositis lebih rendah dari pada kelompok kontrol dengan nilai $p$ $<0,05$, artinya adanya hubungan cryotherapy dengan mukositis oral pada pasien kanker. ${ }^{11}$

Cryotherapy merupakan terapi modalitas keperawatan berupa intervensi yang paling mudah diakses, lebih murah, praktis, efisien, hemat biaya, dan dapat mencegah atau menurunkan skala mukositis oral. Cryotherapy akan lebih efektif lagi hasilnya jika di lakukan perawatan murlut seperti menggososk gigi. Pada penelitian ini, oral hygiene (sikat gigi) terlebih dahulu dilakukan sebelum cryotherapy dilaksanakan pada kelompok cryotherapy. Menggosok gigi dapat membantu mengurangi pembentukan plek atau karang gigi. Hal ini sesuai dengan hasil studi Hasibuan yang melaporkan bahwa insiden mukositis oral berkurang sebesar 38\% terhadap perawatan mulut menggosok gigi). ${ }^{18}$ Cryotherapy juga dapat menjaga kelembapan mulut dengan meningkatkan asupan cairan peroral dan meningkatkan produksi saliva. ${ }^{6}$

\section{SIMPULAN}

Cryotherapy mampu menurunkan skala mukositis oral pada pasien kanker payudara dengan kemoterapi kombinasi 5-fluorouracil.

\section{SARAN}

Penelitian selanjutnya dapat meneliti cryotherapy pada regimen kemoterapi yang lain dengan kanker yang berbeda seperti kanker usus atau kanker serviks.

\section{UCAPAN TERIMAKASIH}

Terimakasih kepada responden, Pimpinan dan Staff RSUP Dr.M.Djamil, khususnya ruang kemoterapi dan seluruh pihak yang terlibat dalam memberikan motivasi, bimbingan dan kerjasama dalam penelitian ini.

\section{DAFTAR PUSTAKA}

1. Andinata B. Deteksi dini kanker payudara Indonesia; 2017 April (diunduh 2 September 2019). Tersedia dari: http://p2tm.kemkes.go.id

2. Badan Penelitian dan Pengembangan Kesehatan (Balitbangkes). Hasil utama Riskesdas 2018. Indonesia; 2018 November (diunduh 2 September 2019). Tersedia dari: http://www.depkes.co.id

3. Komite Penanggulangan Kanker Nasional (KPKN) Panduan penatalaksanaan kanker payudara. Jakarta: KPKN; 2017.

4. Sonis ST. Oral mucositis. Edisi ke-1. Tamsin Curtis, editor. UK: Springer Healthcare; 2015. hlm. 39-46.

5. Portas J, Correa D, Queija D, Arantes LMRB, Viana $L$ de $S$, Carvalho $A$. Effect of induction chemotherapy on swallowing in head and neck cancer patients. Asian Pacific J Cancer Prev. 2019;20(1):91-6.

6. Chang CZ, Hsiang CY, Ho TY, Wu CZ, Hong H, et al. Comprehensive assessment of host responses to 5-fluorouracil-induced oral mucositis through transcriptomic analysis. PLoS One. 2015;10(8):1-14.

7. Kadakia KC, Rozell SA, Butala AA, Loprinzi C. Supportive cryotherapy: a review from head to toe. Bone. 2014;23(1):1-7. 
8. Martin CA, Perez MGS. Prevention and treatment of oral mucositis in patients receiving chemotherapy. J Clin Exp Dent . 2014;6(1):74-80.

9. Hashemil A, Bahrololoumi Z, Khaksar Y, Saffarzadeh $N$, Neamatzade $H$, Foroughi $E$. Mouth-rinses for the prevention of chemotherapy induced oral mucositis in children: a systematic review. Iran J Pediatr Hematol Oncol. 2015;5(2):106-12.

10. Sonis ST. Mucositis: the impact, biology and therapeutic opportunities of oral mucositis. Oral Oncol. 2009;45(12):1015-20.

11. Heydari A, Sharifi H, Salek R. Effect of Oral Cryotherapy on combination chemotherapyinduced oral mucositis : a randomized clinical trial. Middle East J Cancer. 2012;3(2 dan 3):55-64.

12. Eghbali A, Taherkhanchi B, Bagheri B, Sadeghi Sedeh B. Effect of chewing gum on oral mucositis in children undergoing chemotherapy: a randomized controlled study. Iran J Pediatr Hematol Oncol. 2016;6(1):9-14.

13. Nawi RIM, Chui PL, Ishak WZ, Chan CMH. Oral cryotherapy. Clin J Oncol Nurs. 2018;22(5):555-9.

14. Svanberg A, Ohrn K, Birgegård G. Five-year follow-up of survival and relapse in patients who received cryotherapy during high-dose chemotherapy for stem cell transplantation shows no safety concerns. Eur J Cancer Care (Engl). 2012;21(6):822-8.
15. Rashad HM, Darwish MM, Khaled WZ. Effect of cryotherapy on the occurrence of stomatitis induced by chemotherapy among children with bone tumors in Egypt. J Biol Agriculculture Healthc. 2014;4(18):49-58.

16. Wodzinski A. Potential benefits of oral cryotherapy for chemotherapy-induced mucositis. Clin J Oncol Nurs. 2016;20(5):462-5.

17. Owlia F, Kazemeini SK, Gholami N. Prevention and management of mucositis in patients with cancer: a review article. Iran J Cancer Prev. 2012;5(4):216-20.

18. Hasibuan C, Lubis B, Rosdiana N, Nafianti S, Siregar OR. Perawatan mulut untuk pencegahan mukositis oral pada penderita kanker anak yang mendapat kemoterapi. Jurnal Cerminan Dunia Kedokteran. 2019; 46(6):432-5.

19. Peake JM, Roberts L, Figueiredo V, Egner I, Krog $\mathrm{S}$, Aas $\mathrm{S}$, et al. Cryotherapy: are we freezing the benefits of exercise? Temperature. 2017; 4 (3): 211-3.

20. Abdo J, Cornell DL, Mittal SK, Agrawal DK. Immunotherapy plus cryotherapy: potential augmented abscopal effect for advanced cancers. Front Oncol. 2018;8(MAR):1-16.

21. Katranci N, Ovayolu O, Sevinc A. Evaluation of the effect of cryotherapy in preventing oral mucositis associated with chemotherapy a randomized controlled trial. Eur J Oncol Nurs. 2012;16:339-44. 